\title{
Analisis Regresi untuk Memprediksi Tahanan Kapal Cepat
}

\author{
Mohammad Haidar Alvin ${ }^{1}$, Mohammad Atok ${ }^{2}$, Mahendra Indiaryanto ${ }^{3}$ \\ 1,2 Departemen Statistika, Institut Teknologi Sepuluh Nopember (ITS) \\ ${ }^{3}$ Laboratorium Hidrodinamika, Badan Pengkajian dan Penerapan Teknologi (BPPT) \\ E-mail: indiaryanto@gmail.com
}

\begin{abstract}
Abstrak - Kapal merupakan bagian penting dari kehidupan manusia, terutama dalam bidang transportasi laut. Industri perkapalan di Indonesia telah berkembang dengan pesat, ditandai dengan berdirinya galangan-galangan kapal di Indonesia. Tahap awal dalam proses pembuatan kapal adalah menentukan ukuran dan parameter bentuk kapal. Bersamaan dengan hal tersebut terdapat faktor penting yang berhubungan dengan performa kapal, yaitu tahanan kapal. Kesalahan perhitungan tahanan kapal dapat berdampak buruk terhadap performa kapal dan juga para stakeholder kapal. Salah satu metode statistika yang memungkinkan untuk memprediksi tahanan kapal berdasarkan pengujian tahanan model kapal, yaitu analisis regresi. Pemilihan metode regresi sangat diperlukan karena metode yang tepat akan menghasilkan prediksi yang tepat juga. Pemilihan metode regresi dipengaruhi oleh kondisi data penelitian, seperti terpenuhi atau tidaknya asumsi-asumsi klasik meliputi multikolinieritas, distribusi normal, autokorelasi, dan homoskedastisitas. Hasil pengujian asumsi menunjukan asumsi multikolinieritas dan distribusi normal tidak dapat terpenuhi yang mengarahkan pada penggunaan metode regresi robust ridge.
\end{abstract}

Kata Kunci-Autokorelasi, Homoskedastisitas, Multikolinieritas, Robust Ridge.

\section{PENDAHULUAN}

$\mathrm{S}$ EJARAH peradaban manusia telah menjadikan kapal sebagai alat pendorong utama untuk eksplorasi wilayah teritorial dan juga pengembangan ilmu pengeta-huan. Perkembangan kapal berjalan pesat seiring dengan perkembangan umat manusia. Kapal-kapal khusus di-bangun untuk fungsi yang sepenuhnya baru, seperti kapal pemadam kebakaran, penyelamatan, dan kapal penelitian. Indonesia sebagai negara kepulauan tentunya sangat bergantung terhadap kapal. Pemanfaatan kapal di Indonesia telah mencakup dalam berbagai bidang, seperti logistik, trasportasi massal, dan juga militer.

Pada dasarnya kapal dapat dibedakan ke dalam dua kategori, yaitu menurut bentuk lambung kapal dan menurut fungsinya. Pengelompokan tipe kapal menurut bentuk lambung dapat dibedakan menjadi empat jenis, yaitu kapal Aerostatic, kapal Hydrostatic, kapal Hydrodinamic, dan kapal Multi Lambung. Pengelompokan kapal berdasarkan fungsinya terbagi menjadi tiga, yaitu kapal niaga dan komersil, kapal perang, dan kapal khusus [1]. Kapal perang adalah jenis kapal yang dirancang khusus untuk penggunaan kekuatan angkatan laut. Kapal perang berbeda dari kapal dagang dan sipil dalam hal desain, konstruksi, dan penggunaan.

Tahap awal dalam proses teknis pembuatan kapal adalah menentukan ukuran dan parameter bentuk kapal, namun selain hal tersebut terdapat salah satu faktor penting yang berpengaruh terhadap kemampuan kapal, yaitu tahanan kapal atau resistance force [2]. Prinsip dasar pendekatan dalam perhitungan desain kekuatan struktur konstruksi kapal adalah melalui pertimbangan bahwa badan kapal sebagai sebuah balok memanjang yang berada diatas tumpuan media fluida dalam hal ini gelombang laut yang mempunyai tekanan (fluid pressure) dan gaya dinamis (dynamic forces). Berdasarkan hal tersebut, prediksi taha-nan kapal sangatlah penting untuk dilakukan sebelum kapal tersebut dibangun. Balai Teknologi Hidrodinamika Badan Pengkajian dan Penerapan Teknologi (BTH-BPPT) meru-pakan salah satu lembaga di Indonesia yang dapat mela-kukan pengujian tahanan kapal. Biaya pengujian tahanan kapal masih tergolong mahal [3]. Maka dari itu, penyingkatan waktu uji tentunya sangat berpengaruh bagi BTH-BPPT dari segi ekonomi.

Salah satu metode statistika yang memungkinkan untuk memprediksi tahanan kapal berdasarkan pengujian tahanan model kapal, yaitu analisis regresi [4]

Pemodelan meng-gunakan analisis regresi merupakan salah satu teknik dalam analisis data yang bertujuan untuk menjelaskan hubungan antara variabel prediktor dengan variabel respon [5]. Ter-dapat berbagai metode dan model regresi yang berkembang hingga saat ini. Setiap metode memiliki keunggulan dan peruntukan masing-masing. Model regresi linier sederhana memiliki dua parameter, yaitu $\beta_{0}$ dan $\beta_{1}$ yang mana besar koefisiennya diperoleh dari data. Sebagai metode para-metrik, tentunya diharuskan adanya pemenuhan asumsi-asumsi klasik. Walaupun demikian, teknik prediksi dengan memodelkan data menggunakan regresi tetap digunakan hingga saat ini.

Tahanan kapal berhubungan dengan besarnya daya mesin kapal yang dibuthkan. Untuk itu, tahanan kapal telah menjadi suatu keterikatan dan pertimbangan terpenting dalam konstruksi kapal. Tahap awal pembentukan kapal, yaitu merancang model kapal menggunakan faktor-faktor yang akan menjadi karakteristik dari kapal tersebut. Karakteristik kapal sangat menentukan besar dan kecilnya tahanan suatu kapal. Proses perhitungan yang panjang dan rumit dalam pembuatan model kapal tentu diperlukan sebagai langkah awal untuk mendapatkan besarnya tahanan kapal. Tahap akhir untuk mendapatkan tahanan kapal tentunya proses pengujian model kapal menggunakan carriage pada towing tank. Faktor-faktor pada karakteristik kapal yang diduga berpengaruh dalam pembentukan tahanan kapal dapat dimodelkan secara statistik meng-gunakan regresi. Model regresi yang didapatkan dari faktor-faktor yang diduga berpengaruh dapat digunakan sebagai acuan untuk memprediksi besarnya tahanan suatu kapal.

\section{TINJAUAN PUSTAKA}

\section{A. Regresi Linier Berganda}

Analisis hubungan atau pengaruh satu variabel prediktor terhadap satu variabel respon dapat menggunakan model 
regresi linier sederhana. Sedangkan untuk melakukan analisis hubungan atau pengaruh dua atau lebih variabel prediktor terhadap variabel respon, maka model regresi yang digunakan adalah model regresi linier berganda [6]. Kemudian untuk mendapatkan model regresi linier sederhana maupun model regresi linier berganda dapat diperoleh dengan melakukan estimasi terhadap parameterparameternya menggunakan metode tertentu. Bentuk umum persamaan dari regresi linier berganda ditunjukkan sebagai berikut:

$$
\begin{gathered}
y_{i}=\beta_{0}+\beta_{1} x_{1 i}+\beta_{2} x_{2 i}+\cdots+\beta_{k} x_{j i}+\varepsilon_{i} \\
\text { dengan, } i=1,2, \ldots, n ; j=1,2, \ldots, p ; k=0,1, \ldots, q
\end{gathered}
$$

Berdasarkan bentuk umum persamaan dari regresi linier berganda di atas, maka persamaan dapat diseder-hanakan menjadi persamaan berikut [5]:

$$
\boldsymbol{Y}=\boldsymbol{X} \boldsymbol{\beta}+\boldsymbol{\varepsilon}
$$

Estimasi parameter $\beta$ bertujuan untuk mendapatkan model regresi linier berganda yang akan digunakan dalam analisis. Metode yang digunakan untuk mengestimasi parameter model regresi linier berganda berdasarkan asumsi normalitas data adalah metode Ordinary Least Square atau OLS [7]. Metode OLS bertujuan meminimumkan jumlah kuadrat dari residual. Penaksir OLS merupakan penaksir yang memiliki sifat Best Linier Unbiased Estimator (BLUE). Persamaan untuk penaksiran parameter $\beta$ ditunjukkan sebagai berikut:

$$
\widehat{\boldsymbol{\beta}}=\left(\boldsymbol{X}^{\prime} \boldsymbol{X}\right)^{-\mathbf{1}}\left(\boldsymbol{X}^{\prime} \boldsymbol{Y}\right)
$$

Regresi sebagai metode parametrik tentunya mempunyai asumsi-asumsi yang harus dipenuhi agar model regresi tidak bias. Asumsi pada regresi linier berganda akan disebutkan sebagai berikut dalam buku [7]:

1. Data linier dalam parameter.

2. Kemiripan variansi residual data (homoskedasitas).

3. Residual berdistribusi normal.

4. Tidak terdapat kolinearitas antar variabel prediktor (multikolinearitas).

\section{B. Regresi Ridge}

Regresi Ridge merupakan metode regresi untuk menduga koefisien parameter regresi dengan menambahkan konstanta bias $c$ pada diagonal matriks $\left(\boldsymbol{X}^{\prime} \boldsymbol{X}\right)$ [8]. Regresi Ridge bergantung pada sebuah transformasi normalisasi variabel prediktor. Hal tersebut dilakukan dengan mengurangi dari setiap nilai yang merupakan estimasi rata-rata prediktor dan membagi masing-masing nilai dengan estimasi standar deviasi prediktor. Melalui cara tersebut, semua nilai berada pada skala yang sama dan memiliki standar deviasi 1. Regresi Ridge memberikan penalti pada ukuran total koefisien, sehingga model dengan koefisien yang lebih kecil lebih diutamakan.

Metode regresi Ridge dapat digunakan untuk mengatasi korelasi yang tinggi antar beberapa variabel independen (prediktor) atau dalam kata lain metode ini mampu mengatasi multikolinearitas yang terjadi pada kasus regresi linier berganda [8]. Meskipun metode ini akan menghasilkan parameter dugaan yang sedikit bias namun parameter dugaan tersebut dapat menghasilkan parameter yang memiliki nilai taksiran mendekati nilai sebenarnya.

Estimasi (pendugaan) parameter Ridge dinotasikan sebagai $\widehat{\boldsymbol{\beta}}^{*}$ dan untuk mendapatkan penduga parameter Ridge diperlukan penurunan fungsi Lagrange terhadap $\widehat{\boldsymbol{\beta}}^{*}$.
Penjabaran formula untuk penduga parameter ridge seperti pada persamaan (4).

$$
\widehat{\boldsymbol{\beta}}^{*}=\left[c \boldsymbol{I}+\left(\boldsymbol{X}^{\prime} \boldsymbol{X}\right)\right]^{-\mathbf{1}} \boldsymbol{X}^{\prime} \boldsymbol{Y}
$$

\section{Regresi Robust}

Salah satu ide untuk mengatasi masalah dalam regresi yang umum muncul adalah mengidentifikasi outlier, menghapusnya, dan kemudian melanjutkan seperti langkah awal, dan diasumsikan bahwa set data telah sesuai untuk metode standar. Jika koefisien sebenarnya diketahui, maka outlier tidak akan sulit dideteksi. Bidang diagnosa regresi mencoba untuk mengatasi masalah bagai-mana mengidentifikasi titik-titik dan outlier yang berpengaruh, yang mana dalam kasus umum ketika kita tidak mengetahui nilainilai koefisien sebenarnya.

Pendekatan statistik untuk berurusan dengan outlier adalah regresi yang kuat (robust regression), yang mencoba untuk menghasilkan estimator yang resisten atau setidaknya tidak sangat dipengaruhi oleh outlier [9]. Dalam mem-pelajari residual dari regresi robust, mungkin outlier yang sebenarnya dapat ditemukan. Dalam bidang ini banyak ide yang berbeda telah diusulkan, termasuk Least Trimmed Squares (LTS), Least Median of Squares (LMS), M-estimators, GMestimators, dan S-estimators [10]. Model dasar dari regresi robust sama dengan model regresi linier berganda. Hal yang membedakan hanya pada metode estimasi parameter model.

Metode regresi robust memiliki banyak cara dalam mengestimasi parameter yang robust. MM-Estimator lebih efisien dibandingkan dua metode yang telah disebutkan sebelumnya dalam penelitian [10]. Berdasarkan penjabaran singkat mengenai metode $M$-Estimator dan $S$-Estimator yang telah disebutkan sebelumnya, estimasi parameter robust pada penelitian ini menggunakan MM-Estimator. MM-Estimator merupakan perpaduan antara M-Estimator dan S-Estimator yang memiliki breakdown point tertinggi dan efisiensi yang tinggi terhadap normalitas [9]. Penaksiran parameter robust meng-gunakan MM-Estimator dijelaskan melalui persamaan (5).

$$
\begin{gathered}
\widehat{\boldsymbol{\beta}}_{\text {Robust }}=\widehat{\boldsymbol{\beta}}_{\boldsymbol{M M}}=\sum_{i=1}^{n} x_{i j} \varphi_{1}\left(\frac{y_{i}-x_{i}^{T} \widehat{\beta}}{S_{n}}\right)=0, \\
\operatorname{dimana} j=1,2, \ldots, k \\
\boldsymbol{S}_{\boldsymbol{n}}=S\left(r_{i}(\tilde{\beta}), \ldots, r_{n}(\tilde{\beta})\right) \\
\boldsymbol{r}_{\boldsymbol{i}}(\boldsymbol{\beta})=y_{i}-x_{i}^{T} \tilde{\beta} \\
\boldsymbol{\varphi}_{\mathbf{1}}(\boldsymbol{\varepsilon})=\frac{\partial \rho_{1}(\varepsilon)}{\partial \varepsilon}
\end{gathered}
$$

Melalui persamaan (5) di atas, maka estimasi parameter robust menggunakan MM-Estimator dapat dise-derhanakan seperti pada persamaan (6).

$$
\widehat{\boldsymbol{\beta}}_{M M}=\left(\boldsymbol{X}^{T} w_{i} \boldsymbol{X}\right)^{-1}\left(\boldsymbol{X}^{T} w_{i} \boldsymbol{y}\right)
$$

dimana,

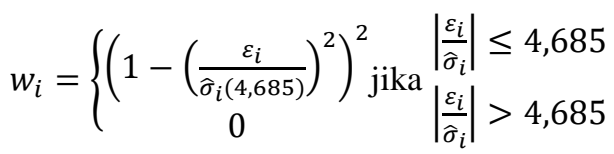

\section{Regresi Robust Ridge}

Regresi ridge dengan parameter robust merupakan sebuah penggabungan dua metode regresi, yaitu regresi ridge dan regresi robust. Metode ini lebih dikenal dengan nama robust ridge regression. Tujuan dari metode ini adalah untuk 
mengatasi pelanggaran asumsi distribusi normal dan multikolinieritas yang tidak dapat diatasi oleh metode regresi linier berganda OLS. Konsep dasar dari regresi robust ridge menggunakan teknik pemodelan regresi ridge dengan menyisipkan parameter robust dalam kalkulasi parameter model ridge.

Ketika kasus outlier dan multikolinieritas terjadi dalam dataset, akan lebih bermanfaat untuk meng-gabungkan metode yang dirancang untuk menangani masalah tersebut secara individual. Dengan demikian, estimator ridge yang robust akan tahan terhadap masalah multikolinieritas dan akan lebih sedikit terpengaruh oleh outlier dibandingkan dengan metode regresi ridge [11].

Persamaan (7) merupakan estimasi parameter robust untuk regresi ridge. Notasi $\widehat{\boldsymbol{\beta}}^{* *}$ merupakan matriks dari taksiran parameter robust untuk regresi ridge.

$$
\widehat{\boldsymbol{\beta}}^{* *}=\left[c^{*} \boldsymbol{I}+\left(\boldsymbol{X}^{\prime} \boldsymbol{X}\right)\right]^{-\mathbf{1}} \boldsymbol{X}^{\prime} \boldsymbol{X} \widehat{\boldsymbol{\beta}}_{\boldsymbol{M M}}
$$

Telah banyak metode untuk mencari nilai $c^{*}$ dijelaskan dalam berbagai literatur. Pada penelitian ini, metode perhitungan $c^{*}$ dipilih metode yang diformulasikan oleh Hoerl, Kennard, dan Baldwin [8]. Formula kalkulasi nilai $c^{*}$ tersebut disajikan pada persamaan (8).

$$
c^{*}=\frac{k \widehat{\sigma}_{R o b u s t}^{2}}{\widehat{\boldsymbol{\beta}}_{M M}^{\prime} \widehat{\boldsymbol{\beta}}_{M M}}
$$

dimana,

\section{$k \quad:$ Jumlah regresor \\ $\hat{\sigma}_{\text {Robust }}^{2}$ : Estimator variansi robust \\ E. Validasi dan Kriteria Kebaikan Model}

Pada permasalahan regresi, estimasi parameter regresi dan kesalahan standar (standard error) yang dihasilkan oleh model mengarahkan para peneliti untuk melakukan evaluasi terhadap model. Evaluasi kebaikan model regresi dalam memprediksi variabel respon telah dikembangkan dan memiliki berbagai macam cara [7]. Validasi silang (cross validation) merupakan metode untuk mengevaluasi model regresi yang akan digunakan untuk memprediksi tahanan kapal. Prinsip dasar validasi silang, yaitu membagi data penelitian menjadi dua subset data atau lebih [12]. Jika menggunakan dua subset data, maka salah satu subset tersebut akan digunakan untuk membentuk model sementara subset lain digunakan untuk validasi hasil prediksi. Validasi silang memiliki berbagai jenis metode yang salah satunya adalah hold out cross validation.

$\mathrm{R}^{2}$ merupakan salah satu metode yang dapat digunakan untuk melihat kebaikan model regresi berdasarkan kriteria informasi yang dihasil-kan oleh variabel prediktor untuk memprediksi variabel respon. Secara singkat, jika $R^{2}$ digunakan untuk melihat seberapa baik garis regresi untuk mencocokkan terhadap data. Nilai $\mathrm{R}^{2}$ memiliki interval antara 0 sampai 1 dan tidak bernilai negatif. Perhitungan $\mathrm{R}^{2}$ didefinisikan sebagai berikut:

$$
R^{2}=\frac{\sum_{i=1}^{n}\left(y_{i}-\hat{y}_{i}\right)^{2}}{\sum_{i=1}^{n}\left(y_{i}-\bar{y}\right)^{2}}
$$

dimana:

$$
\begin{array}{ll}
R^{2} & : \text { Koefisien determinasi } \\
y_{i} & \text { : Data observasi aktual ke-i } \\
n & : \text { Banyak pengamatan }
\end{array}
$$

Metode lain untuk melakukan penilaian kebaikan model regresi adalah Root Mean Square Error (RMSE). RMSE adalah aturan penilaian kuadrat yang mengukur besarnya rata-rata ke-salahan (error) dari model. RMSE merupakan akar kuadrat dari rata-rata perbedaan kuadrat antara data hasil prediksi dan observasi actual [12]. Rumusan RMSE didefinisikan pada persamaan (10).

$$
R M S E=\sqrt[2]{\frac{\sum_{i=1}^{n}\left(y_{i}-\hat{y}_{i}\right)^{2}}{n}}
$$

\section{F. Kapal Cepat}

Kapal cepat merupakan kapal yang memiliki bilangan Froude lebih dari sama dengan 0,35 saat berlayar[13]. Kapal cepat dapat ditemui dengan mudah di lingkungan pesisir dan juga laut lepas. Terdapat banyak desain untuk berbagai jenis kapal cepat, namun satu desain yang pasti adalah bentuk lambung kapal yang menyerupai huruf ' $V$ '. Kapal cepat lebih banyak diperuntukkan sebagai kapal perang dan patroli. Kapal perang dan patroli difungsikan sebagai kapal pemantau dari kegiatan-kegiatan yang terjadi di laut khususnya kegiatan yang sekiranya berpotensi atau bahkan telah melanggar peraturan yang telah ditetapkan[1].

\section{G. Tahanan Kapal}

Resistensi atau tahanan kapal pada kecepatan tertentu adalah gaya yang diperlukan untuk menarik kapal pada kecepatan itu dalam air yang halus, dengan asumsi tidak ada gangguan dari kapal yang ditarik. Kapal yang bergerak dengan kecepatan tertentu pasti akan mengalami tahanan (resistance) yang besarnya tergantung dari banyak faktor dari kapal itu sendiri, namun hal yang paling utama karena arahnya yang berlawanan dengan arah gerak kapal itu sendiri [14]. Berikut merupakan rumus untuk tahanan total berdasarkan metode Guldhammer dan Harvald:

$$
R_{T}=\frac{1}{2} \rho C_{T} S V^{2}
$$

dimana,

$$
\begin{array}{ll}
R_{T} & : \text { Total Tahanan Kapal }(\mathrm{kN}) \\
\rho & : \text { Masa Jenis Air } \\
C_{T} & : \text { Koefisien Total } \\
S & : \text { Wetted Surface Area }\left(\mathrm{m}^{2}\right) \\
V & : \text { Kecepatan kapal }(\mathrm{knot} \text { atau } \mathrm{m} / \mathrm{s})
\end{array}
$$

Kapal memerlukan kekuatan tertentu untuk mencapai kecepatan yang diinginkan. Kekuatan tersebut harus menyesuaikan dengan besarnya total tahanan kapal agar kapal mampu melawan tahanan kapal dan dapat melaju dengan baik. Kekuatan yang diperlukan untuk mengatasi perlawanan ini disebut sebagai towrope atau kekuatan efektif dan dijabarkan pada persamaan (12) berikut ini [15].

$$
P_{E}=R_{T} V
$$

dimana,

$P_{E}:$ Daya Efisien Mesin Kapal $(\mathrm{kW})$

\section{METODOLOGI PENELITIAN}

Data yang digunakan dalam penelitian ini adalah data sekunder yang diperoleh dari pengujian yang dilakukan oleh Balai Teknologi Hidrodinamika Badan Pengkajian dan Penerapan Teknologi (BTH-BPPT). Data berasal dari hasil pengujian tahanan kapal patroli yang dilakukan pada towing tank dari tahun 2011 sampai 2018. Proses pengujian berlangsung selama 1-2 bulan mulai dari pembuatan purwarupa, pengujian tahanan kapal, hingga pembuatan 
Tabel 1.

Variabel Penelitian

\begin{tabular}{|c|c|c|c|}
\hline Variabel & Simbol & Deskripsi & $\begin{array}{c}\text { Skala } \\
\text { Pengukuran }\end{array}$ \\
\hline $\mathrm{X}_{1}$ & $L_{W L}$ & $\begin{array}{l}\text { Panjang kapal tercelup air } \\
\text { (m) }\end{array}$ & Rasio \\
\hline $\mathrm{X}_{2}$ & $B$ & Lebar kapal tercelup air (m) & Rasio \\
\hline $\mathrm{X}_{3}$ & $T_{F}$ & $\begin{array}{l}\text { Sarat tercelup air bagian } \\
\text { depan }(\mathrm{m})\end{array}$ & Rasio \\
\hline $\mathrm{X}_{4}$ & $\operatorname{Disp} / \Delta$ & $\begin{array}{l}\text { Total keseluruhan berat } \\
\text { kapal (Ton) }\end{array}$ & Rasio \\
\hline $\mathrm{X}_{5}$ & $C_{B}$ & Koefisien Blok & Rasio \\
\hline $\mathrm{X}_{6}$ & $C_{M}$ & Koefisien Midship & Rasio \\
\hline $\mathrm{X}_{7}$ & $S$ & Area Dibasahi $\left(\mathrm{m}^{2}\right)$ & Rasio \\
\hline $\mathrm{X}_{8}$ & $V^{2}$ & Kecepatan Kapal (knot) & Rasio \\
\hline $\mathrm{Y}$ & $R_{T}$ & Tahanan Kapal (kN) & Rasio \\
\hline
\end{tabular}

laporan pengujian. Setiap pengamatan uji tahanan kapal dilakukan selama 7-14 hari. Variabel yang digunakan pada penelitian ini terdiri dari delapan variabel prediktor yang diduga berpengaruh terhadap prediksi tahanan kapal cepat.

Langkah analisis yang digunakan pada penelitian ini adalah sebagai berikut.

1. Mengumpulkan data penelitian yang berupa data sekunder.

2. Menentukan variabel yang akan digunakan dalam penelitian.

3. Eksplorasi data dan mendeskripsikan faktor-faktor yang diduga mempengaruhi pemodelan tahanan kapal.

4. Melakukan uji linieritas data menggunakan Ramsey RESET Test.

5. Melakukan pemodelan menggunakan analisis regresi dan pendugaan parameter.

6. Melakukan uji asumsi klasik regresi linier berganda, yaitu :
a. Homoskedastisitas
b. Autokorelasi
c. Distribusi Normal
d. Multikolinieritas

7. Menentukan ulang metode regresi yang sesuai dengan hasil uji asumsi dan memodelkan kembali.

8. Melakukan validasi silang menggunakan metode hold out.

9. Melakukan perhitungan RMSE dan MAE dari model, dan melihat kebaikan model.

10. Mengintepretasi dan memilih model terbaik.

11. Menarik kesimpulan dan saran dari hasil analsis.

\section{HASIL DAN PEMBAHASAN}

\section{A. Statistika Deskriptif}

Statistika deskriptif didasarkan tentang eksplorasi dan menyajikan data dengan baik. Salah satu cara dalam mendeskripsikan sebuah data, yaitu dengan membuat plot atau grafik distribusi data. Informasi mengenai seluruh variabel penelitian disajikan dalam Tabel 1.

Berdasarkan Tabel 2 dapat diketahui bahwa tahanan kapal terkecil dari objek penelitian berada pada angka $6,8 \mathrm{kN}$, sedangkan tahanan kapal terbesar berada pada angka $461 \mathrm{kN}$. Rata-rata tahanan kapal cepat didapatkan sebesar $158,8 \mathrm{kN}$ dengan variansi data sebesar 7610,76. Selain itu, kecepatan kapal berdasarkan data pengujian berada pada nilai 17 knot untuk yang terkecil dan 28 knot untuk yang terbesar. Angka 17 knot dan 28 knot didapatkan dari akar nilai yang ada pada Tabel 2. variabel $\mathrm{X}_{8}$. Statistika deskriptif lain yang dapat
Tabel 2.

Statistika Deskriptif Variabel Penelitian

\begin{tabular}{llrrrrr}
\hline \hline & Variabel & \multicolumn{1}{c}{ Min } & \multicolumn{1}{c}{ Max } & \multicolumn{1}{c}{ Med } & \multicolumn{1}{c}{ Mean } & \multicolumn{1}{c}{ Var } \\
\hline $\mathrm{Y}$ & $R_{T}$ & 6,80 & 461,00 & 141,50 & 158,80 & 7610,76 \\
$\mathrm{X}_{1}$ & $L_{W L}$ & 8,89 & 76,15 & 42,80 & 42,99 & 276,91 \\
$\mathrm{X}_{2}$ & $B$ & 2,80 & 16,00 & 7,80 & 7,73 & 6,71 \\
$\mathrm{X}_{3}$ & $T_{F}$ & 0,45 & 3,00 & 1,80 & 1,82 & 0,42 \\
$\mathrm{X}_{4}$ & Disp/ & 4,00 & 1626,00 & 235,40 & 327,60 & 112062,70 \\
$\mathrm{X}_{5}$ & $C_{B}$ & 0,23 & 0,54 & 0,40 & 0,42 & 0,01 \\
$\mathrm{X}_{6}$ & $C_{M}$ & 0,40 & 0,93 & 0,60 & 0,63 & 0,01 \\
$\mathrm{X}_{7}$ & $S$ & 19,35 & 1041,88 & 303,47 & 355,65 & 5309,00 \\
$\mathrm{X}_{8}$ & $V^{2}$ & 289,00 & 784,00 & 484,00 & 509,80 & 21511,88 \\
\hline \hline
\end{tabular}

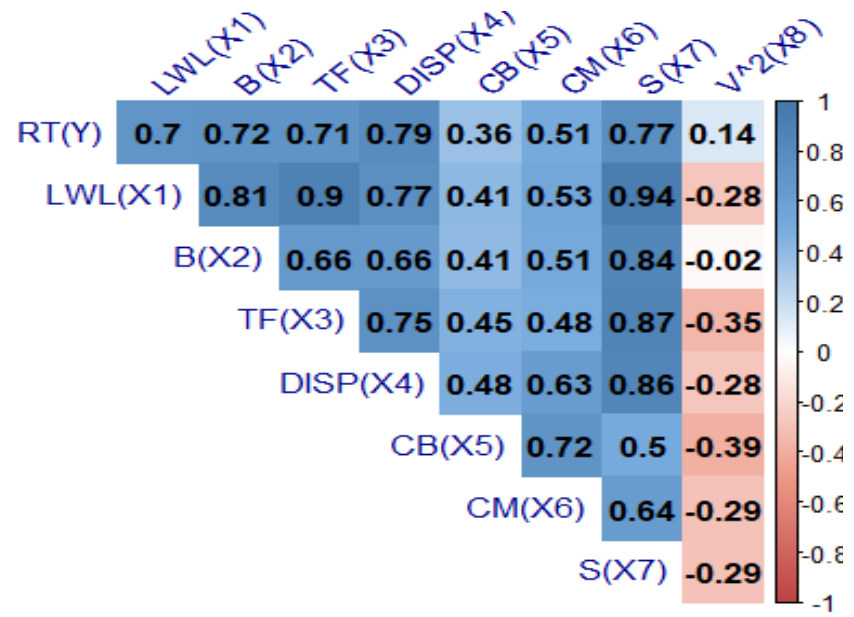

Gambar 1. Matriks Korelasi Variabel Penelitian

digunakan untuk melihat hubungan antar dua variabel penelitian adalah korelasi. Visualisasi matriks korelasi disajikan pada Gambar 1 untuk mempermudah pembaca dalam melihat besaran korelasi antar variabel.

Pada Gambar 1 semakin gelap warna biru maka menunjukkan kedua variabel memiliki korelasi positif yang semakin kuat. Sementara semakin gelap warna merah maka menunjukkan kedua variabel memiliki korelasi negatif yang semakin kuat. Jika warna pada Gambar 1 semakin muda atau mendekati ke arah warna putih, maka dapat dinyatakan kedua variabel memiliki korelasi yang sangat lemah. Hubungan antara variabel $\mathrm{R}_{\mathrm{T}}(Y)$ dengan variabel Disp/ $\Delta \quad\left(X_{4}\right)$ merupakan korelasi terkuat yang terjadi antara variabel respon dengan variabel prediktor dengan nilai korelasi sebesar 0,79 . Nilai korelasi yang paling tinggi dimiliki variabel $\mathrm{L}_{\mathrm{WL}}\left(X_{l}\right)$ dengan variabel $\mathrm{S}\left(X_{7}\right)$. Nilai korelasi kedua variabel tersebut sebesar 0,94 yang menunjukkan kedua variabel memiliki hubungan yang sangat kuat. Korelasi kuat antar variabel prediktor dapat dijadikan indikasi bahwa adanya kasus multikolinieritas. Untuk melihat bagaimana pesebaran data dari masing-masing variabel prediktor dapat digunakan boxplot yang disajikan pada Gambar 2. Boxplot juga berguna untuk mendeteksi ada atau tidaknya outlier dari masing-masing variabel.

Berdasarkan Gambar 2, dapat dilihat bahwa Variabel B $\left(\mathrm{X}_{2}\right)$ memiliki data outlier sebanyak empat pengamatan. Sementara variabel Disp/ $\Delta\left(X_{4}\right)$ terdapat outlier di dalamnya sebanyak tiga pengamatan. Outliers digambarkan seperti tanda " $\mathrm{x}$ " berwarna merah pada masing-masing boxplot. Variabel $\mathrm{C}_{\mathrm{B}}\left(X_{5}\right), \mathrm{C}_{\mathrm{M}}\left(X_{6}\right)$, dan $\mathrm{S}\left(X_{7}\right)$ juga terdapat data outlier sebanyak satu data. Sementara itu, variabel responmemiliki satu outlier pada data yang merupakan data terbesar pada variabel respon. Statistika deskriptif lain yang dapat digunakan dalam penelitian ini adalah memvisualisasikan kecendrungan hubungan antara variabel respon dan variabel prediktor. Teknik visualisasi yang 


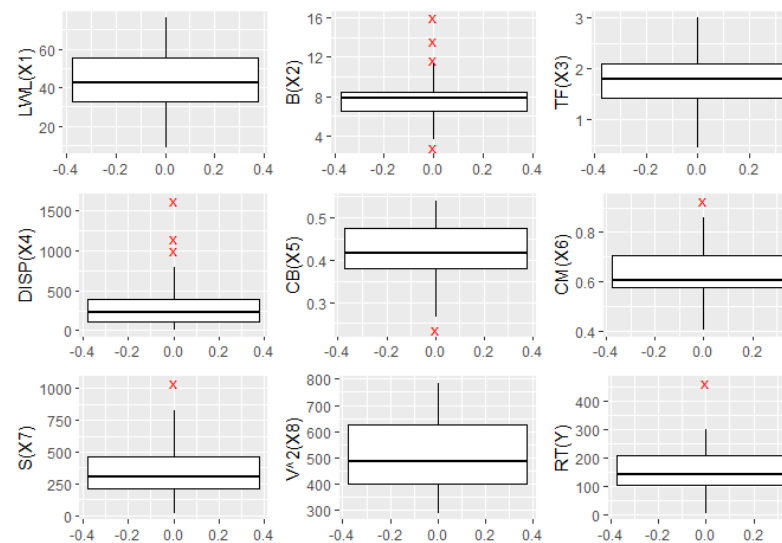

Gambar 2. Boxplot Variabel Penelitian

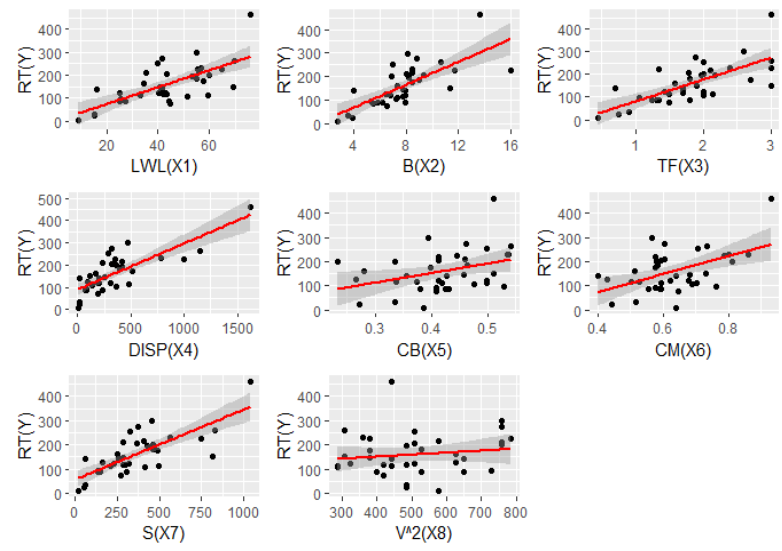

Gambar 3. Scatterplot Variabel X dengan Y

digunakan adalah scatterplot dengan tambahan fit line di dalamnya untuk membantu proses pendugaan apakah antar variabel tersebut memiliki kencendrungan hubungan linier atau tidak.

Hasil visualisasi pola hubungan dari masing-masing variabel seperti pada Gambar 3 akan digunakan sebagai pertimbangan dalam mendeteksi hubungan linieritas antara variabel respon dan variabel prediktor. Scatterplot antara variabel $\mathrm{R}_{\mathrm{T}}(\mathrm{Y})$ dengan variabel $\mathrm{L}_{\mathrm{WL}}\left(\mathrm{X}_{1}\right)$ yang disajikan pada Gambar 3 mengindikasikan hubungan yang linier. Hal ini tergambarkan melalui sebaran data yang mengikuti garis linier (fit line). Pola hubungan antara variabel $\mathrm{R}_{\mathrm{T}}(\mathrm{Y})$ dengan variabel $\mathrm{B}\left(\mathrm{X}_{2}\right)$ memiliki kecendrungan hubungan yang linier. Meskipun begitu, hubungan linier antara $\mathrm{R}_{\mathrm{T}}(\mathrm{Y})$ dengan $\mathrm{B}\left(\mathrm{X}_{2}\right)$ belum dapat dipastikan melalui visualisasi karena terdapat kecendrungan penumpukan data pada satu titik meskipun pesebarannya mengikuti garis linier (fit line).

Gambar 3 juga menyajikan informasi pola hubungan linier antara variabel $\mathrm{R}_{\mathrm{T}}(\mathrm{Y})$ dengan empat variabel predik-tor lain, yaitu $\mathrm{T}_{\mathrm{F}}\left(X_{3}\right), \mathrm{C}_{\mathrm{B}}\left(X_{5}\right), \mathrm{C}_{\mathrm{M}}\left(X_{6}\right)$, dan $\mathrm{V}^{2}\left(X_{8}\right)$. Sementara itu, variabel $\mathrm{S}\left(X_{7}\right)$ dapat diyakinkan melalui visualisasi tidak memiliki hubungan yang linier dengan variabel $\mathrm{R}_{\mathrm{T}}(Y)$. Pemantauan hubungan linier antara variabel respon dengan variabel prediktor tidak cukup jika hanya melalui visualisasi scatterplot. Langkah selanjutnya yang harus dilakukan adalah melakukan pengujian hubungan linieritas data yang pada penelitian ini menggunakan metode Ramsey RESET Test.

\section{B. Uji Linieritas Data}

Uji linieritas data diperlukan sebagai salah satu syarat peme-nuhan asumsi jika menggunakan analisis regresi linier
Tabel 3.

Hasil Uji Linieritas Data

\begin{tabular}{lcrrr}
\hline \hline Variabel & RESET Statistik & $\mathrm{df}_{1}$ & $\mathrm{df}_{2}$ & $p$-value \\
\hline $\mathrm{Y} \sim \mathrm{X}_{1}$ & 3,0298 & 2 & 33 & 0,0619 \\
$\mathrm{Y} \sim \mathrm{X}_{2}$ & 1,9798 & 2 & 33 & 0,1542 \\
$\mathrm{Y} \sim \mathrm{X}_{3}$ & 0,0027 & 2 & 33 & 0,9973 \\
$\mathrm{Y} \sim \mathrm{X}_{4}$ & 5,8913 & 2 & 33 & 0,0064 \\
$\mathrm{Y} \sim \mathrm{X}_{5}$ & 1,2285 & 2 & 33 & 0,3058 \\
$\mathrm{Y} \sim \mathrm{X}_{6}$ & 4,5989 & 2 & 33 & 0,0173 \\
$\mathrm{Y} \sim \mathrm{X}_{7}$ & 4,2261 & 2 & 33 & 0,0232 \\
$\mathrm{Y} \sim \mathrm{X}_{8}$ & 2,4597 & 2 & 33 & 0,1010 \\
\hline \hline
\end{tabular}

Tabel 4.

Bentuk Transformasi Variabel Penelitian

\begin{tabular}{|c|c|c|c|c|}
\hline Variabel & $\begin{array}{c}\text { Metode } \\
\text { Transformasi }\end{array}$ & Variabel & \multicolumn{2}{|c|}{ Metode Transformasi } \\
\hline $\mathrm{Y}$ & $\mathrm{Y}$ & $\mathrm{X}_{5}$ & \multicolumn{2}{|r|}{$\mathrm{X}_{5}$} \\
\hline $\mathrm{X}_{1}$ & $\mathrm{X}_{1}$ & $X_{6}$ & & $\left(X_{6}\right)^{3}$ \\
\hline $\mathrm{X}_{2}$ & $\mathrm{X}_{2}$ & $\mathrm{X}_{7}$ & & $\left(X_{7}\right)^{1 / 2}$ \\
\hline $\mathrm{X}_{3}$ & $\mathrm{X}_{3}$ & $\mathrm{X}_{8}$ & & $\mathrm{X}_{8}$ \\
\hline \multicolumn{5}{|c|}{$\left(\mathrm{X}_{4}\right)^{1 / 3}$} \\
\hline \multicolumn{5}{|c|}{$\begin{array}{l}\text { Tabel } 5 . \\
\text { Linieritas Data Transformasi }\end{array}$} \\
\hline Variabel & RESET Statistik & $=\mathrm{df}_{1}$ & $\overline{d f_{2}}$ & p-value \\
\hline $\mathrm{Y} \sim\left(\mathrm{X}_{4}\right)^{1 / 3}$ & 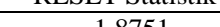 & $\frac{5}{411}$ & $\frac{312}{32}$ & $P=160$ \\
\hline $\mathrm{Y} \sim\left(\mathrm{X}_{4}\right)^{-10}$ & $1,8 / 51$ & 2 & 33 & 0,1693 \\
\hline $\mathrm{Y} \sim\left(\mathrm{X}_{6}\right)^{3}$ & 3,2638 & 2 & 33 & 0,0508 \\
\hline $\mathrm{Y} \sim\left(\mathrm{X}_{7}\right)^{1 / 2}$ & 1,3255 & 2 & 33 & 0,2794 \\
\hline
\end{tabular}

berganda. Metode pengujian yang digunakan dalam penelitian adalah Ramsey RESET Test. $H_{0}$ pada pengujian ini adalah data memiliki hubungan yang linier. Jika hasil pengujian memberikan keputusan untuk menolak $H_{0}$, maka data tidak memiliki hubungan linier. Hasil dari Ramsey RESET Test dapat dilihat pada Tabel 3.

Tabel 3 di atas memperlihatkan hasil pengujian linieritas data antara variabel respon dengan variabel prediktor. Melihat besaran $p$-value, diketahui bahwa variabel yang memiliki hubungan linier terhadap variabel $\mathrm{R}_{\mathrm{T}}(\mathrm{Y})$ adalah variabel $\mathrm{L}_{\mathrm{WL}}\left(\mathrm{X}_{1}\right), \mathrm{B}\left(\mathrm{X}_{2}\right), \mathrm{T}_{\mathrm{F}}\left(\mathrm{X}_{3}\right), \mathrm{C}_{\mathrm{B}}\left(\mathrm{X}_{5}\right)$, dan $\mathrm{V}^{2}\left(\mathrm{X}_{8}\right)$. Untuk itu, dapat diputuskan variabel-variabel yang tidak memiliki hubungan linier terhadap variabel $\mathrm{R}_{\mathrm{T}}(\mathrm{Y})$, yaitu Disp/ $\Delta\left(\mathrm{X}_{4}\right), \mathrm{C}_{\mathrm{M}}\left(\mathrm{X}_{6}\right)$, dan $\mathrm{S}\left(\mathrm{X}_{7}\right)$. Keputusan tersebut didapatkan berdasarkan be-saran $p$-value yang didapat melebihi dari taraf signifikan $\alpha=5 \%$ atau sebesar 0,05 . Langkah selanjutnya yang dapat dilakukan adalah melakukan transformasi data variabel prediktor hingga asumsi linieritas dapat terpenuhi. Metode transformasi data yang dilakukan harus berlandaskan pada pola sebaran data sehingga data hasil transformasi menjadi linier. Metode transformasi data penelitian yang dilakukan disajikan pada Tabel 4 .

Transformasi hanya dilakukan pada variabel prediktor yang tidak memiliki hubungan linier terhadap variabel respon. Setelah proses transformasi data dilakukan, uji linieritas data yang telah ditransformasi perlu dilakukan kembali untuk memastikan variabel tersebut telah linier.Tabel 5 berisikan hasil Ramsey RESET Test dari variabel yang telah ditransformasi.

Berdasarkan hasil Tabel 5 terlihat jelas bahwa variabel Disp/ $\Delta\left(\mathrm{X}_{4}\right), \mathrm{C}_{\mathrm{M}}\left(\mathrm{X}_{6}\right)$, dan $\mathrm{S}\left(\mathrm{X}_{7}\right)$ telah linier terhadap variabel $\mathrm{R}_{\mathrm{T}}(\mathrm{Y})$. Keputusan tersebut didapat berdasarkan $p$-value yang bernilai kurang dari $\alpha=5 \%$. Langkah selanjut-nya yang dapat dilakukan adalah memodelkan data meng-gunakan regresi linier berganda untuk melakukan pengujian asumsi lain seperti homoskedastisitas dan distribusi normal yang didasarkan pada residual model. 
Tabel 6

Hasil Uji Asumsi

\begin{tabular}{|c|c|c|c|c|}
\hline Metode & $\begin{array}{l}\text { Statistik } \\
\text { Uji }\end{array}$ & $\mathrm{df}_{1}$ & $p$-value & Keterangan \\
\hline $\begin{array}{l}\text { Breusch- } \\
\text { Pagan }\end{array}$ & 0,0003 & 1 & 0,9856 & Gagal Tolak $H_{0}$ \\
\hline Jarque-Bera & 95,427 & 18 & 0,0000 & Tolak $H_{0}$ \\
\hline \multicolumn{5}{|c|}{$\begin{array}{c}\text { Tabel } 7 . \\
\text { Hasil Uji Asumsi Multikolinieritas } \\
\end{array}$} \\
\hline \multicolumn{3}{|c|}{ Variabel } & \multicolumn{2}{|r|}{$V I F$} \\
\hline \multicolumn{3}{|c|}{$\mathrm{X}_{1}$} & \multicolumn{2}{|r|}{37,0689} \\
\hline \multicolumn{3}{|c|}{$\mathrm{X}_{2}$} & \multicolumn{2}{|r|}{9,3290} \\
\hline \multicolumn{3}{|c|}{$\mathrm{X}_{3}$} & \multicolumn{2}{|r|}{11,7261} \\
\hline \multicolumn{3}{|c|}{$\mathrm{X}_{4}$} & \multicolumn{2}{|r|}{6,3864} \\
\hline \multicolumn{3}{|c|}{$\mathrm{X}_{5}$} & \multicolumn{2}{|r|}{2,0662} \\
\hline \multicolumn{3}{|c|}{$\mathrm{X}_{6}$} & \multicolumn{2}{|r|}{2,3992} \\
\hline \multicolumn{3}{|c|}{$\mathrm{X}_{7}$} & \multicolumn{2}{|r|}{95,5422} \\
\hline \multicolumn{3}{|c|}{$\mathrm{X}_{8}$} & \multicolumn{2}{|r|}{1,5171} \\
\hline
\end{tabular}

\section{Uji Asumsi Klasik Regresi}

Uji asumsi pertama yang dapat dilakukan setelah melakukan uji linieritas data adalah uji asumsi homoskedastisitas. $H_{0}$ pada pengujian ini adalah data ber-sifat homoskedastisitas. Metode pengujian yang digunakan adalah Breusch-Pagan Test. Uji asumsi terakhir adalah uji asumsi distri-busi normal dengan menggunakan metode Jarque-Bera Test. $H_{0}$ yang digunakan pada pengujian ini, yaitu data mengikuti pola distribusi normal. Hasil dari setiap uji disajikan dalam Tabel 5.

Berdasarka Tabel 5 di atas menunjukkan bahwa hasil pengujian asumsi homoskedastisitas menggunakan metode Breusch-Pagan memberikan keputusan bahwa asumsi homoskedastisitas telah terpenuhi karena gagal menolak $H_{0}$. Lain hal dengan uji asumsi distribusi normal yang memberikan kesimpulan bahwa model tidak berdistribusi normal karena keputusan menghasilkan untuk menolak $H_{0}$. Terdapat satu asumsi lain yang perlu dipenuhi dalam kasus regresi linier berganda, yaitu asumsi multikolinieritas. Pemeriksaan pelanggaran asumsi multikolinieritas dapat menggunakan metode VIF. Hasil pengujian disajikan pada Tabel 6.

Pada Tabel 6 dapat dilihat bahwa terdapat tiga variabel prediktor dengan nilai VIF lebih dari 10. Sesuai dengan ketentuan mengenai pemenuhan asumsi multikolinieritas menggunakan VIF, maka diputuskan bahwa variabel $\mathrm{X}_{1}, \mathrm{X}_{3}$, dan $\mathrm{X}_{7}$ tidak memenuhi asumsi multikolinieritas. Kesimpulan yang didapat berdasarkan hasil pengujian asumsi klasik regresi linier berganda, yaitu data hanya me-menuhi asumsi homoskedastisitas. Asumsi distribusi normal dan juga multikolinieritas tidak dapat terpenuhi sehingga metode regresi linier berganda tidak relevan untuk digunakan sebagai metode pemodelan dalam analisis lebih lanjut. Mengarah pada hasil uji asumsi regresi linier berganda, maka diputuskan untuk melakukan pemodelan data penelitian menggunakan metode regresi ridge dengan parameter robust (robust ridge regression).

\section{Pemodelan Regresi Robust}

Pada penelitian ini, dilakukan pemodelan regresi robust dengan membandingkan empat metode estimasi parameter robust. Keempat metode tersebut, yaitu MM-Estimator, $S$ Estimator, Least Trimmed Square (LTS), dan Least Median
Tabel 8.

Hasil RMSE dan R2 Model Robust

\begin{tabular}{ccc}
\hline \hline Metode & RMSE & $\mathrm{R}^{2}$ \\
\hline MM & 38,5608 & 0,8112 \\
LMS & 82,5867 & 0,3989 \\
LTS & 69,5980 & 0,5128 \\
S & 39,7661 & 0,8274 \\
\hline \hline
\end{tabular}

Tabel 9.

Koefisien Parameter Robust MM-Estimator

\begin{tabular}{lrr}
\hline \hline & \multicolumn{1}{c}{ Koefisien } & Standar Error \\
\hline$\beta_{0}$ & $-220,0407$ & 33,3516 \\
$\beta_{1}$ & $-3,4135$ & 1,3834 \\
$\beta_{2}$ & 2,7333 & 4,4596 \\
$\beta_{3}$ & 62,0874 & 20,0827 \\
$\beta_{4}$ & 19,4446 & 4,3979 \\
$\beta_{5}$ & $-4,7347$ & 67,9376 \\
$\beta_{6}$ & $-12,2643$ & 36,5871 \\
$\beta_{7}$ & 7,9731 & 5,9402 \\
$\beta_{8}$ & 0,2455 & 0,0318 \\
\hline \hline
\end{tabular}

of Square (LMS). Membandingkan keempat metode tersebut berguna untuk memperkuat pernyataan bahwa $M M$ Estimator merupakan metode pendugaan para-meter yang lebih efisien. Tujuan dilakukan langkah ini adalah untuk mendapatkan parameter robust terbaik yang nantinya digunakan dalam melakukan penaksiran parameter ridge yang robust. Tabel 7 menyajikan hasil Root Mean Square Error (RMSE) dan $\mathrm{R}^{2}$ dari masing-masing model.

Tabel 7 menunjukkan model dengan nilai RMSE terkecil dimiliki oleh model robust dengan MM-Estimator. $\mathrm{R}^{2}$ terbesar dimiliki oleh model robust dengan S-Estimator dan model robust dengan MM-Estimator yang hanya mempunyai selisih kurang dari $1 \%$. Meskipun demikian dalam memilih metode yang memiliki estimasi terbaik, indikator yang paling utama untuk dipertimbangkan adalah nilai RMSE. Setelah memastikan metode yang akan digunakan sebagai parameter robust, analisis selanjutnya yang memodelkan data menggunakan regresi ridge dengan parameter robust dapat dilakukan. Koefisien parameter robust yang menggunakan MM-Estimator sebagai metode pendugaannya dapat dilihat pada tabel 8 .

Tabel 8 memperlihatkan koefisien estimasi parameter regresi robust menggunakan MM-Estimator dan standard error masing-masing parameter. Standard error terkecil dimiliki oleh parameter $\beta_{8}$ dengan nilai sebesar 0,0318 . Sementara standard error terbesar dimiliki oleh parameter $\beta_{5}$. Standard error mendeskripsikan jarak antara data hasil prediksi dengan garis regresi. Semakin besar standard error maka semakin jauh jarak data prediksi dari garis regresi.

\section{E. Pemodelan Regresi Robust Ridge}

Penduga parameter robust telah didapatkan, namun model robust yang telah diformulasikan seperti sub-bab sebelumnya masih belum relevan untuk digunakan. Hal ini, dikarenakan data yang dimiliki mengandung multikolinieri-tas. Sementara regresi robust hanya mampu mengatasi asumsi distribusi normal yang tidak terpenuhi dan outlier. Pemodelan menggunakan regresi robust ridge diharapkan menghasilkan model dengan nilai RMSE dan $\mathrm{R}^{2}$ yang lebih baik dibandingkan dengan model regresi robust maupun regresi linier.

Regresi ridge memiliki konstanta bias c yang digunakan sebagai regularisasi dalam model agar model rigde menjadi efisien. Untuk memilih nilai $c$ optimum diperlukan simulasi memodelkan data menggunakan regresi robust ridge dengan 
Tabel 10

Koefisien Parameter Robust Ridge MM-Estimator

\begin{tabular}{lrr}
\hline \hline & \multicolumn{1}{c}{ Koefisien } & \multicolumn{1}{c}{$p$-value } \\
\hline$\beta_{0}$ & $-162,175$ & 0,000 \\
$\beta_{1}$ & 0,126 & 0,394 \\
$\beta_{2}$ & 4,428 & 0,000 \\
$\beta_{3}$ & 33,984 & 0,000 \\
$\beta_{4}$ & 11,801 & 0,000 \\
$\beta_{5}$ & 13,337 & 0,719 \\
$\beta_{6}$ & 10,927 & 0,568 \\
$\beta_{7}$ & 1,879 & 0,000 \\
$\beta_{8}$ & 0,185 & 0,000 \\
\hline \hline
\end{tabular}

Tabel 11 .

Hasil RMSE dan $\mathrm{R}^{2}$ Model

\begin{tabular}{|c|c|c|}
\hline Obs & 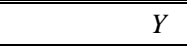 & $\widehat{Y}_{\text {RobustRidge }}$ \\
\hline 2 & 174,214 & 157,218 \\
\hline 5 & 279,055 & 248,260 \\
\hline 26 & A. 120,745 & 129,844 \\
\hline 27 & 114,317 & 121,221 \\
\hline 36 & 112,994 & 130,424 \\
\hline
\end{tabular}

berbagai nilai $c$. Hasil simulasi dapat dilihat pada bagian lampiran. Besaran nilai $c$ optimum yang didapat, yaitu $c=0,2$ dengan mempertimbangkan tidak adanya koefisien parameter yang bertanda negatif dan juga nilai $\mathrm{R}^{2}$ terbesar.

Untuk memastikan bahwa model regresi robust ridge dapat digunakan untuk memprediksi tahanan kapal cepat diperlukan aplikasi metode validasi silang. Validasi silang dilakukan dengan mempartisi data menjadi dua bagian, yaitu bagian training dan testing. Validasi silang dilakukan dengan membagi $80 \%$ data (32 dari total 37 pengamatan) sebagai data training yang akan digunakan untuk membentuk model regresi. Sementara $20 \%$ sisa dari data digunakan sebagai data testing yang akan digunakan untuk mengevaluasi model yang terbentuk. Data testing terdiri dari data pengamatan ke-2, ke5, ke-26, ke-27, dan data pengamatan ke-36. Estimasi parameter yang didapatkan dengan besaran $c=0,2$ melalui pemodelan ini disajikan dalam Tabel 9.

Setelah melalui proses pemodelan, didapatkan besaran $p$ value pada Tabel 9 yang dapat digunakan untuk melakukan pengujian signifikansi parameter model secara parsial. Terlihat bahwa parameter yang memiliki pengaruh signifikan, diantaranya $\beta_{2}, \beta_{3}, \beta_{4}, \beta_{7}$, dan $\beta_{8}$. Lima parameter tersebut memiliki $p$-value kurang dari taraf signifikan $\alpha$ sebesar 5\%. Model akhir dari regresi robust ridge disajikan pada persamaan (13).

$$
\begin{gathered}
\hat{Y}_{R R}=\quad-162,175+0,126 X_{1}+4,428 X_{2}+ \\
33,984 X_{3}+11,801 X_{4}^{\frac{1}{3}}+ \\
13,337 X_{5}+10,927 X_{6}{ }^{3}+ \\
1,879 X_{7}{ }^{1 / 2}+0,185 X_{8}
\end{gathered}
$$

Model regresi pada persamaan (13) dapat digunakan untuk memprediksi tahanan kapal cepat dengan memasuk-kan nilai dari faktor-faktor yang berpengaruh. Hasil prediksi tahanan kapal cepat dan data asli tahanan kapal disajikan pada Tabel 10.

Hasil prediksi pada Tabel 10 terdapat perbedaan, namun perbedaan tersebut tidak terlalu jauh dari nilai sebenarnya. Selain itu, hasil prediksi menggunakan regresi robust ridge tidak menghasilkan nilai negatif yang menandakan bahwa kasus multikolinieritas pada model telah teratasi dengan baik.
Tabel 12.

Hasil RMSE dan $\mathrm{R}^{2}$ Model

\begin{tabular}{lcc}
\hline \hline \multicolumn{1}{c}{ Metode } & RMSE & $\mathrm{R}^{2}$ \\
\hline Linear & 33,179 & 0,940 \\
Robust & 36,509 & 0,870 \\
Robust Ridge & 18,284 & 0,983 \\
\hline \hline
\end{tabular}

Tabel 13.

$\mathrm{R}^{2}$ Pemilihan Nilai $c$ Optimum

\begin{tabular}{llll}
\hline \hline \multicolumn{1}{c}{$\mathbf{c}$} & $R^{2}$ & \multicolumn{1}{c}{$\mathbf{c}$} & $R^{2}$ \\
\hline & 0,919 & $\mathrm{c}=0,55$ & 0,647 \\
$\mathrm{c}=0,1$ & 0,871 & $\mathrm{c}=0,6$ & 0,630 \\
$\mathrm{c}=0,15$ & 0,834 & $\mathrm{c}=0,65$ & 0,615 \\
$\mathrm{c}=0,2$ & 0,801 & $\mathrm{c}=0,7$ & 0,600 \\
$\mathrm{c}=0,25$ & 0,773 & $\mathrm{c}=0,75$ & 0,587 \\
$\mathrm{c}=0,3$ & 0,747 & $\mathrm{c}=0,8$ & 0,573 \\
$\mathrm{c}=0,35$ & 0,724 & $\mathrm{c}=0,85$ & 0,561 \\
$\mathrm{c}=0,4$ & 0,703 & $\mathrm{c}=0,9$ & 0,549 \\
$\mathrm{c}=0,45$ & 0,683 & $\mathrm{c}=0,95$ & 0,537 \\
$\mathrm{c}=0,5$ & 0,664 & - & - \\
\hline \hline
\end{tabular}

\section{F. Validasi \& Kebaikan Model}

Untuk membuktikan apakah regresi robust ridge lebih baik untuk mengatasi dua kasus pelanggaran asumsi, dilakukan kalkulasi RMSE dan $\mathrm{R}^{2}$ dari model. Tabel 11 menyajikan RMSE dan $\mathrm{R}^{2}$ dari model regresi robust dan robust ridge.

Hasil kriteria kebaikan model robust ridge pada Tabel 11 didapatkan RMSE sebesar 18,284. Nilai RMSE model robust ridge tersebut lebih kecil jika dibandingkan dengan model regresi robust dan juga regresi linier. Koefisien determinasi atau $\mathrm{R}^{2}$ model regresi robust ridge juga memiliki nilai yang lebih besar dibandingkan dengan $\mathrm{R}^{2}$ model regresi robust dan linier, yaitu sebesar $0,983 \approx 98,3 \%$.

Melalui hasil tersebut dapat dikatakan bahwa kebaikan parameter robust ridge dalam memprediksi nilai tahanan kapal cepat pada kasus ini dapat dipercaya karena model mampu meprediksi dengan kebaikan sebesar 98,3\%.

\section{KESIMPULAN DAN SARAN}

Pada penelitian ini sebanyak delapan variabel prediktor dilakukan analisis deskriptif dan didapatkan hasil bahwa variabel $\mathrm{B}\left(\mathrm{X}_{2}\right)$, Disp/ $\Delta\left(\mathrm{X}_{4}\right), \mathrm{C}_{\mathrm{M}}\left(\mathrm{X}_{6}\right)$, dan $\mathrm{S}\left(\mathrm{X}_{7}\right)$ terdapat outlier. Hasil pengujian linieritas data menguatkan bahwa variabel Disp/ $\Delta\left(\mathrm{X}_{4}\right), \mathrm{C}_{\mathrm{M}}\left(\mathrm{X}_{6}\right)$, dan $\mathrm{S}\left(\mathrm{X}_{7}\right)$ tidak linier terhadap variabel $\mathrm{R}_{\mathrm{T}}(\mathrm{Y})$. Untuk itu, proses transformasi data dilakukan untuk mendapatkan data yang linier.

Melalui tahap pemodelan Tabel 12 regresi ridge dengan menggunakan parameter yang robust mampu menjawab permasalahan multikolinieritas dan ketidaknormalan data. Melalui intepretasi model terdapat faktor-faktor yang paling berpengaruh terhadap pembentukan tahanan kapal, yaitu variabel $\mathrm{B}\left(\mathrm{X}_{2}\right), \mathrm{T}_{\mathrm{F}}\left(\mathrm{X}_{3}\right)$, Disp/ $\Delta\left(\mathrm{X}_{4}\right), \mathrm{S}\left(\mathrm{X}_{7}\right)$, dan $\mathrm{V}^{2}\left(\mathrm{X}_{8}\right)$. Lima faktor tersebut secara statistik memiliki pengaruh yang signifikan terhadap prediksi tahanan kapal cepat pada taraf signifikan sebesar 5\%.

Model akhir robust ridge dengan Tabel $13 \mathrm{R}^{2}$ model sebesar 0,983 merupakan model terbaik yang didapatkan melalui data pengujian tahanan kapal cepat. $\mathrm{R}^{2}$ model sebesar 0,983 memiliki arti bahwa banyaknya informasi yang mampu dijelaskan oleh model sebesar 98,3\%. Sekitar 2,7\% informasi lainnya dijelaskan oleh variabel yang tidak berada di dalam model tersebut. Model regresi terbaik dapat digunakan untuk memprediksi tahanan kapal cepat dengan memasukkan 
Tabel 14.

Simulasi Regresi Robust Ridge

\begin{tabular}{|c|c|c|c|c|c|c|c|c|c|}
\hline $\mathrm{c}$ & $\beta_{0}$ & $\beta_{1}$ & $\beta_{2}$ & $\beta_{3}$ & $\beta_{4}$ & $\beta_{5}$ & $\beta_{6}$ & $\beta_{7}$ & $\beta_{8}$ \\
\hline $\mathrm{c}=0,05$ & $-207,743$ & $-0,835$ & 4,461 & 54,303 & 15,994 & 17,165 & 0,628 & 1,908 & 0,234 \\
\hline $\mathrm{c}=0,1$ & $-194,278$ & $-0,308$ & 4,174 & 45,707 & 14,049 & 19,58 & 4,155 & 1,825 & 0,221 \\
\hline $\mathrm{c}=0,15$ & $-182,203$ & $-0,045$ & 4,134 & 40,404 & 12,761 & 18,924 & 6,715 & 1,853 & 0,208 \\
\hline$c=0,2$ & $-171,516$ & 0,113 & 4,169 & 36,741 & 11,821 & 17,688 & 8,747 & 1,882 & 0,197 \\
\hline$c=0,25$ & $-161,999$ & 0,216 & 4,221 & 34,019 & 11,093 & 16,501 & 10,419 & 1,901 & 0,187 \\
\hline$c=0,3$ & $-153,451$ & 0,288 & 4,27 & 31,895 & 10,505 & 15,527 & 11,826 & 1,912 & 0,177 \\
\hline$c=0,35$ & $-145,706$ & 0,341 & 4,309 & 30,177 & 10,017 & 14,788 & 13,026 & 1,916 & 0,169 \\
\hline$c=0,4$ & $-138,632$ & 0,38 & 4,337 & 28,751 & 9,602 & 14,262 & 14,063 & 1,915 & 0,161 \\
\hline$c=0,45$ & $-132,128$ & 0,41 & 4,355 & 27,542 & 9,243 & 13,916 & 14,965 & 1,911 & 0,154 \\
\hline$c=0,5$ & $-126,111$ & 0,434 & 4,364 & 26,5 & 8,928 & 13,717 & 15,757 & 1,904 & 0,148 \\
\hline$c=0,55$ & $-120,515$ & 0,452 & 4,366 & 25,588 & 8,647 & 13,637 & 16,455 & 1,895 & 0,142 \\
\hline $\mathrm{c}=0,6$ & $-115,287$ & 0,466 & 4,361 & 24,781 & 8,396 & 13,651 & 17,073 & 1,885 & 0,137 \\
\hline$c=0,65$ & $-110,381$ & 0,477 & 4,351 & 24,059 & 8,168 & 13,738 & 17,623 & 1,873 & 0,132 \\
\hline$c=0,7$ & $-105,762$ & 0,486 & 4,336 & 23,409 & 7,96 & 13,881 & 18,113 & 1,86 & 0,127 \\
\hline$c=0,75$ & $-101,399$ & 0,493 & 4,318 & 22,818 & 7,769 & 14,068 & 18,552 & 1,847 & 0,123 \\
\hline$c=0,8$ & $-97,264$ & 0,499 & 4,298 & 22,277 & 7,592 & 14,288 & 18,945 & 1,834 & 0,119 \\
\hline$c=0,85$ & $-93,337$ & 0,503 & 4,274 & 21,78 & 7,429 & 14,532 & 19,297 & 1,82 & 0,115 \\
\hline$c=0,9$ & $-89,597$ & 0,506 & 4,249 & 21,32 & 7,276 & 14,793 & 19,613 & 1,806 & 0,111 \\
\hline$c=0,95$ & $-86,027$ & 0,509 & 4,222 & 20,892 & 7,133 & 15,065 & 19,896 & 1,792 & 0,108 \\
\hline$c=1$ & $-82,614$ & 0,51 & 4,194 & 20,492 & 6,999 & 15,344 & 20,151 & 1,778 & 0,104 \\
\hline
\end{tabular}

besaran variabel prediktor ke dalam model pada persamaan (13).

Saran untuk penelitian kedepannya, disarankan bagi pembaca/penelitian selanjutnya untuk melakukan analisis menggunakan regresi ridge dengan metode penduga parameter yang lebih baik. Untuk penelitian serupa dengan jumlah data yang lebih banyak, disarankan untuk menggunakan metode in sample out sample yang lebih mendukung agar didapatkan model prediksi dengan akurasi dan presisi yang lebih tinggi. Simulasi Regresi Robust Ridge dapat dilihat pada Tabel 14 .

$$
\begin{gathered}
\hat{Y}=\beta_{0}+\beta_{1} X_{1}+\beta_{2} X_{2}+\beta_{3} X_{3}+\beta_{4} X_{4}^{1 / 3}+\beta_{5} X_{5}+ \\
\beta_{6} X_{6}{ }^{3}+\beta_{7} X_{7}^{1 / 2}+\beta_{8} X_{8} \\
\hat{Y}=-162,175-3,4135 X_{1}+2,7333 X_{2}+62,0874 X_{3}+ \\
19,4446 X_{4}^{1 / 3}-4,7347 X_{5}-12,2643 X_{6}{ }^{3}+ \\
7,9731 X_{7}^{1 / 2}+0,2455 X_{8}
\end{gathered}
$$

\section{DAFTAR PUSTAKA}

[1] S. Mulaksono, Konsep Dasar Kapal, Semester 2. Jakarta: Kementerian Pendidikan dan Kebudayaan, 2013.

[2] S. Sahlan, B. Ali, W. H.N, A. Bisri, and B. A. Adietya, "Pengaruh Bentuk Lambung Kapal Terhadap Pola Aliran Dan Powering Pada Kapal Perairan Sungai Dan Laut," Kapal, vol. 13, no. 1, pp. 1-6, 2016, doi: $10.12777 / \mathrm{kpl} .13 .1 .1-6$.

[3] E. Sugianto and A. Winarno, "Computational Model Tahanan Kapal Untuk Menentukan Kebutuhan Daya Kapal Bulk Carrier 8664 Dwt,” J. Kelaut. Indones. J. Mar. Sci. Technol., vol. 10, no. 2, p. 168, 2018, doi: 10.21107/jk.v10i2.3411.
[4] M.-I. Roh and K.-Y. Lee, Computational ship design. Singapore: Springer Singapore, 2018.

[5] J. O. Rawlings, S. G. Pantula, and D. A. Dickey, Applied regression analysis : a research tool. New York: Springer, 2005.

[6] D. N.R and S. H., Analisis Regresi Terapan. Jakarta: Gramedia Pustaka Utama, 1992.

[7] D. N. Gujarati, Basic econometrics, 4th ed. Boston: Mass :, 2003.

[8] A. E. Hoerl and R. W. Kennard, "Ridge Regression: Applications to Nonorthogonal Problems," Technometrics, vol. 12, no. 1, pp. 69-82, 1970, doi: 10.1080/00401706.1970.10488635.

[9] R. R. Wilcox and H. J. Keselman, "Robust Regression Methods: Achieving Small Standard Errors When There Is Heteroscedasticity," Underst. Stat., vol. 3, no. 4, pp. 2005-2006, 2007, doi 10.1207/s15328031us0304.

[10] A. F. Lukman, O. I. Osowole, and K. Ayinde, "Two stage robust ridge method in a linear regression model," J. Mod. Appl. Stat. Methods, vol. 14, no. 2, pp. 53-67, 2015, doi: 10.22237/jmasm/1446350820.

[11] H. Samkar and O. Alpu, "Ridge regression based on some robust estimators," J. Mod. Appl. Stat. Methods, vol. 9, no. 2, pp. 495-501, 2010, doi: $10.22237 / \mathrm{jmasm} / 1288584960$.

[12] T. Chai and R. R. Draxler, "Root mean square error (RMSE) or mean absolute error (MAE)? -Arguments against avoiding RMSE in the literature," Geosci. Model Dev., vol. 7, no. 3, pp. 1247-1250, 2014, doi: 10.5194/gmd-7-1247-2014.

[13] D. Siswanto, "Teori Tahanan Kapal I," Fak. Teknol. Kelautan, Inst. Teknol., vol. 10, 1988.

[14] I. Burhanuddin, I. R. Kusuma, and S. Sarwito, "Technical Study The Trimaran Ship with Water Jetpropulsion System Powered by Electric Motors," Institut Teknologi Sepuluh Nopember, 2012.

[15] E. V Lewis, Principles of Naval Architecture, Volume II Resistance, Propulsion, and Vibration. The Society of Naval Architects and Marine Engineers, 1988. 